\title{
Effects of Tree Forest Plantations on Soil Physicochemical Properties in the Arboretumof Ruhande,Southern Province of Rwanda
}

\author{
Nsengimana Venuste ${ }^{1,2, *}$ \\ ${ }^{1}$ Lecturer, Department of Mathematics, Science and Physical Education, College of \\ Education, University of Rwanda; \\ ${ }^{2}$ Deputy Director, Centre of Excellence in Biodiversity and Natural Resources Management, \\ College of Science and Technology, University of Rwanda; \\ "Identification and address of the author:Author ID: 57190808169; ORCID: 0000-0001- \\ 5963-8314, email: venusteok@gmail.com
}

\begin{abstract}
Different tree speciesare blamed to have negative effects on soil ecosystems by changing soil physicochemical properties, and hence soil quality. However, few researches to verify this statement were done in Rwanda. This study provides prior information on the effects of planted forest tree species on soil physicochemical properties. It was conducted in the Arboretum of Ruhande, in southern Rwanda. Soil cores were collected in plots of exotic, native and agroforestry tree species. Collected soils were analysed for soil $\mathrm{pH}$, total nitrogen, organic carbon, available phosphorus, aggregate stability, bulk density, soil humidity, cation exchange capacity, and soil texture. Soils sampled under exotic tree species were acidic, rich in soil organic carbon, and in soil available phosphorus. Native and agroforestry tree species offer better conditions in soil $\mathrm{pH}$, soil water content, cation exchange capacity, clay and silt. Less variations in soil total nitrogen and soil bulk density were found in soils sampled under all studied forest types. Research concluded that studiedtree species have different effects on soil physicochemical parameters. It recommended further studies to generalize these findings.
\end{abstract}

Key words: soil, exotic, native, agroforestry, soil properties

\section{Introduction}

Soil is the dominant ecosystem that serves as the storage of transformed organic substances mainly the recycled soil organic carbon (Vignozzi et al. 2019). Soil contributes to the control of water fluxes, and it is the suitable habitat for different terrestrial animal species (Rietz and Van der Putten 2012). Agriculture cannot take place, and different plant communities cannot exist without soil. Around $7 \%$ of the total global soil ecosystem is used for forest plantations (Wood 2018; Jürgensen et al. 2014). Different tree specieswere mainly planted to provide timber, food for humans and animals, fire wood, medicines, opportunities for recreation and 
tourism (Campos et al. 2005). They were also planted for climate and erosion control, carbon sequestration, and for biodiversity conservation (Dyck 2003; Mishra et al. 2003).

Despite the increase in global areaused for forest plantations and their importance to human well being, the implications of forest plantations on soil physicochemical propertiesremain an interesting topic in environmental studies. The difference between exotic, native and agroforestry tree species was mainly explained by the impacts that each tree species may have on soil quality and soil biodiversity (Sjoerd et al. 2018). Some exotic tree species are criticised toincrease soil acidification, and consume high water quantity and soil nutrients, particularly in monodominant stands (Henok et al. 2017; Tesfaye et al. 2016; Jagger and Pender 2003). Agroforestry tree species are appreciated to improve soil fertility and hence the agricultural productivity (Ospina 2017). Native tree species are recognized to enhance biodiversity conservation of wild species and to maintain soil quality (FAO 2014).

Planting tree species such as Ficus (Ficusthonningii), Erythrina (Erythrinaabyssinica), Euphorbia (Euphorbia tirucalli), and Vernonia (Vernoniaamygdalena) was a tradition of Rwandese. These species were mainly used to make compounds around houses (AFF 2011). Reinforcement for planting woody and perennial trees out of household started around 1920 (AFF 2011). Planted tree species include Eucalyptus, Pinus, Acacia, Entandrophragma, Podocarpus, and Polyscias(GoR 2007). The total forest cover of Rwanda's forest plantations is now 428569 (13\%) hectares (GoR 2014), with the target to attain 30\% by 2020. Planted forests were introduced to replace natural forests, to protect soil against erosion, and to create buffer zones around natural and protected areas. They were also planted for the production of firewood, fruit and timber, andfor increasingthe construction materials (AFF 2011).

Effects of planted tree species on soil physicochemical properties are less studied in Rwanda. Some studies focused on carbon stock and fluxes in natural and forest plantations (Nsabimana 2009). Few studies explored the relationships between planted tree species and soil physicochemical parameters indicating the conditions of soil quality. This research provides prior and updated information in relation to the effects of some forest tree species on soil $\mathrm{pH}$, nitrogen, phosphorus, soil organic carbon, aggregate stability, cation exchange capacity, soil water content, soil texture and soil bulk density. Research tested the hypothesis that(1) soil properties differ significantly between studied tree species, and (2) introduced tree species have more negative effects on soil properties than indigenous tree species.

\section{Materials and methods}

\subsection{The area of study}

Samples were collected in the Arboretum of Ruhande (2 $36^{\prime} \mathrm{S}$ and $29^{\circ} 44^{\prime} \mathrm{E}$, Altitude: $1737 \mathrm{~m}$ ) located in southern Province of Rwanda. The Arboretum isdominated by tropical humid climate. The average annual temperature is around $20^{\circ} \mathrm{C}$, and the average annual precipitation is estimated at $1232 \mathrm{~mm}$ (GoR 2018). The soil of the area is a Ferralsol formed from schists 
and granites mixed with mica schist and quartzite (Nsabimana 2008; Verdoodt and Van Ranst 2003). The top soil pH was between 3.9 and 5.4 (Nsabimana et al. 2009). The Arboretum of Ruhande was inhabited by human population and used as a crop land to 1933 (Nsabimana et al. 2009). Its current size is around 200ha, comprising 504 plots, each having the size of 50x50m. Plots are numbered and each of them has an historical database of plant growth measurement and plant management (Nsabimana 2008). Each plot is used for forest plantations dominated by different introduced and indigenous tree species.

Table 1: Treatments, pseudo-replicates plot numbers, stand age and geographic locations of sampled tree plot species in the Arboretum of Ruhande, southern Rwanda.

\begin{tabular}{|c|c|c|c|c|c|c|}
\hline Tree species & Category & $\begin{array}{c}\text { Plot } \\
\text { number }\end{array}$ & $\begin{array}{l}\text { Stand age } \\
\text { (years) }\end{array}$ & Latitude & Longitude & Altitude \\
\hline \multirow{3}{*}{$\begin{array}{l}\text { Calliandracaloth } \\
\text { rysus }\end{array}$} & \multirow{3}{*}{ Agroforestry } & 265 & 34 & $26^{\circ} 7^{\prime} 5.16^{\prime \prime} \mathrm{N}$ & $29^{\circ} 45^{\prime} 13.212^{\prime \prime} \mathrm{E}$ & 1710 \\
\hline & & 267 & 34 & $26^{\circ} 7^{\prime} 7.68^{\prime \prime} \mathrm{N}$ & $29^{\circ} 45^{\prime} 10.836^{\prime \prime} \mathrm{E}$ & 1709 \\
\hline & & 273 & 34 & $26^{\circ} 6^{\prime} 54.72^{\prime \prime} \mathrm{N}$ & $29^{\circ} 45^{\prime} 18.144^{\prime \prime} \mathrm{E}$ & 1705 \\
\hline \multirow{3}{*}{ Cedrellaserata } & \multirow{3}{*}{ Agroforestry } & 56 & 36 & $26^{\circ} 9^{\prime} 45.36^{\prime \prime} \mathrm{N}$ & $29^{\circ} 44^{\prime} 49.488^{\prime \prime} \mathrm{E}$ & 1729 \\
\hline & & 111 & 74 & $26^{\circ} 8^{\prime} 29.76^{\prime \prime} \mathrm{N}$ & $29^{\circ} 45^{\prime} 18.288^{\prime \prime} \mathrm{E}$ & 1731 \\
\hline & & 36 & 82 & $26^{\circ} 7^{\prime} 26.76^{\prime \prime} \mathrm{N}$ & $29^{\circ} 45^{\prime} 36.684^{\prime \prime} \mathrm{E}$ & 1709 \\
\hline \multirow{3}{*}{ Senaspectabilis } & \multirow{3}{*}{ Agroforestry } & 100 & 78 & $26^{\circ} 8^{\prime} 27.24^{\prime \prime} \mathrm{N}$ & $29^{\circ} 45^{\prime} 20.664^{\prime \prime} \mathrm{E}$ & 1712 \\
\hline & & 258 & 69 & $26^{\circ} 9^{\prime} 15.12^{\prime \prime} \mathrm{N}$ & $29^{\circ} 45^{\prime} 25.308^{\prime \prime} \mathrm{E}$ & 1709 \\
\hline & & 264 & 69 & $26^{\circ} 9^{\prime} 4.32^{\prime \prime} \mathrm{N}$ & $29^{\circ} 45^{\prime} 29.844^{\prime \prime} \mathrm{E}$ & 1710 \\
\hline \multirow{3}{*}{$\begin{array}{l}\text { Eucalyptus } \\
\text { grandis }\end{array}$} & \multirow{3}{*}{ Exotic } & 181 & - & $26^{\circ} 10^{\prime} 22.08^{\prime \prime} \mathrm{N}$ & $29^{\circ} 44^{\prime} 50.208^{\prime \prime} \mathrm{E}$ & 1711 \\
\hline & & 218 & 68 & $26^{\circ} 10^{\prime} 21.72^{\prime \prime} \mathrm{N}$ & $29^{\circ} 44^{\prime} 51.972^{\prime \prime} \mathrm{E}$ & 1711 \\
\hline & & 220 & 68 & $26^{\circ} 6^{\prime} 48.96^{\prime \prime} \mathrm{N}$ & $29^{\circ} 45^{\prime} 37.944^{\prime \prime} \mathrm{E}$ & 1698 \\
\hline \multirow{3}{*}{$\begin{array}{l}\text { Eucalyptus } \\
\text { maideni }\end{array}$} & \multirow{3}{*}{ Exotic } & 1 & 85 & $26^{\circ} 9^{\prime} 13.32^{\prime \prime} \mathrm{N}$ & $29^{\circ} 44^{\prime} 48.336^{\prime \prime} \mathrm{E}$ & 1734 \\
\hline & & 179 & 73 & $26^{\circ} 6^{\prime} 51.48^{\prime \prime} \mathrm{N}$ & $29^{\circ} 45^{\prime} 36.036^{\prime \prime} \mathrm{E}$ & 1702 \\
\hline & & 377 & 70 & $26^{\circ} 5^{\prime} 45.6^{\prime \prime} \mathrm{N}$ & $29^{\circ} 45^{\prime} 20.628^{\prime \prime} \mathrm{E}$ & 1679 \\
\hline \multirow{3}{*}{ Grevillea robusta } & \multirow{3}{*}{ Exotic } & 104 & 78 & $26^{\circ} 9^{\prime} 51.48^{\prime \prime} \mathrm{N}$ & $29^{\circ} 44^{\prime} 58.164^{\prime \prime} \mathrm{E}$ & 1710 \\
\hline & & 150 & 35 & $26^{\circ} 9^{\prime} 56.88^{\prime \prime} \mathrm{N}$ & $29^{\circ} 45^{\prime} 12.996^{\prime \prime} \mathrm{E}$ & 1727 \\
\hline & & 322 & 39 & $26^{\circ} 8^{\prime} 23.64^{\prime \prime} \mathrm{N}$ & $29^{\circ} 45^{\prime} 30.096^{\prime \prime} \mathrm{E}$ & 1707 \\
\hline \multirow{3}{*}{$\begin{array}{l}\text { Entandrophragm } \\
\text { aexcelsum }\end{array}$} & \multirow{3}{*}{ Native } & 44 & 70 & $26^{\circ} 9^{\prime} 7.92^{\prime \prime} \mathrm{N}$ & $29^{\circ} 45^{\prime} 08.172^{\prime \prime} \mathrm{E}$ & 1734 \\
\hline & & 54 & 67 & $26^{\circ} 8^{\prime} 13.92^{\prime \prime} \mathrm{N}$ & $29^{\circ} 45^{\prime} 25.848^{\prime \prime} \mathrm{E}$ & 1719 \\
\hline & & 78 & 67 & $26^{\circ} 7^{\prime} 57.36^{\prime \prime} \mathrm{N}$ & $29^{\circ} 45^{\prime} 34.092^{\prime \prime} \mathrm{E}$ & 1708 \\
\hline \multirow{3}{*}{$\begin{array}{l}\text { Podocarpusfalcat } \\
\text { us }\end{array}$} & \multirow{3}{*}{ Native } & 156 & 72 & $26^{\circ} 10^{\prime} 9.48^{\prime \prime} \mathrm{N}$ & $29^{\circ} 44^{\prime} 56.868^{\prime \prime} \mathrm{E}$ & 1708 \\
\hline & & 196 & - & $26^{\circ} 9^{\prime} 39.24^{\prime \prime} \mathrm{N}$ & $29^{\circ} 45^{\prime} 03.348^{\prime \prime} \mathrm{E}$ & 1710 \\
\hline & & 226 & 67 & $26^{\circ} 8^{\prime} 25.44^{\prime \prime} \mathrm{N}$ & $29^{\circ} 45^{\prime} 38.124^{\prime \prime} \mathrm{E}$ & 1697 \\
\hline \multirow{3}{*}{ Polisciasfulva } & \multirow{3}{*}{ Native } & 240 & 69 & $26^{\circ} 9^{\prime} 46.44^{\prime \prime} \mathrm{N}$ & $29^{\circ} 45^{\prime} 09.036^{\prime \prime} \mathrm{E}$ & 1713 \\
\hline & & 262 & 69 & $26^{\circ} 9^{\prime} 6.12^{\prime \prime} \mathrm{N}$ & $29^{\circ} 45^{\prime} 28.728^{\prime \prime} \mathrm{E}$ & 1711 \\
\hline & & 268 & 69 & $26^{\circ} 8^{\prime} 52.8^{\prime \prime} \mathrm{N}$ & $29^{\circ} 45^{\prime} 33.912^{\prime \prime} \mathrm{E}$ & 1700 \\
\hline
\end{tabular}

\subsection{Data collection}


During this study, soil cores were collected in different tree species. Specifically, they were collected in indigenous (native) tree species comprising Polysciasfulva,Podocarpusfalcatus, andEntandrophragmaexcelsum. Samples were also collected in introduced (exotic) tree species composed of Eucalyptus grandis, Eucalyptus maideni, and Grevillea robusta. Further, samples were collected in agroforestrytree species, namely Calliandracalothrysus, Cedrellaserrata, and Senaspectabilis. In each type of forest tree species, three pseudoreplicates were selected. In each pseudo-replicate, data were collected in nine sampling points, each having the size of one-meter square, and in 0-10 cm soil layer depth. The plot number of each pseudo-replicate, age, geographic location and altitude are given in Table 1.

Reference to the research conducted by Nsabimana et al. (2008), a distance of $10 \mathrm{~m}$ from the edge of the sampling plot was left outside of the area of study to reduce edge effects. Further, to minimize the autocorrelation, a distance of $16 \mathrm{~m}$ was maintained between two sampling locations, based on the methodology used by Clark et al. (1996). Samples from the same replicate were bulked together to make one representative sample (Sayad et al. 2012). Samples used for the analysis of soil bulk density were collected following the core sampling method developed by Abu-Hamdeh and Al-Jalil(1999). Finally, each sample was taken to the laboratory of soil analysis and separately analysed for soil properties.

\subsection{Laboratory and statistical data analysis}

Each soil sample was dried and sieved before starting laboratory analysis. After, the suspension made of soil and water was obtained by mixing water with soil at 1:1.5 ratio (Tellen and Yerima, 2018). Then the $\mathrm{pH}$ water $\left(\mathrm{pH}_{\mathrm{w}}\right)$ levels were calculated by using a calibrated pH-meter (Watson and Brown 1998) for each sample. Due to the existence of different types of soil nutrients, the total nitrogen and available phosphorus that are essential for plants were taken into consideration. These nutrients together with the soil organic carbon, cation exchange capacity, bulk density, aggregate stability, water content and texture were calculated following their specific measurement techniques (Nsengimana et al. 2018).

Means within three pseudo-replicates for each treatment of studied tree species were analysed. Effects of tree species were analysed by the non-metric multidimensional scaling (NMDS) following the index of similarity developed by Bray-Curtis (Ashford et al. 2013). Further, the Bray-Curtis dissimilarity analysis was carried out to determine which parameter contributes most to the similarity (Clarke 1993). The ANOVA based on the tests developed by Kruskal-Wallis for equal medians helped to assess differences in soil physicochemical characteristics between plots of introduced, agroforestry and indigenous tree species. Linear correlation coefficients developed by Pearson were used to determine correlations in soil physicochemical parameters, and significant differences were tested at 5\% probability level. The PAST software 3.09 was preferred to run these statistical analysis (Hammer et al. 2001). 


\section{Results}

The mean-age of studied tree species varied from agroforestry $(56.6 \pm 21.4)$, introduced (64.5 $\pm 17.9)$ to indigenous $(69.7 \pm 1.7)$ tree species. Variations in soil physicochemical parameters were not related to the age of studied tree species, and the non-metric multidimensional scaling tests indicated less impacts of studied tree species on soil properties (ANOSIM $=0.3$, $\mathrm{P}>0.5)$. However, significant differences $(\mathrm{P}<0.05)$ were found in studied soil physicochemical parameters. This was supported by the analysis of the overall similarity index (OSI $=7.88 ; \mathrm{P}<0.05)$. The Bray-Curtis similarity index (SI) indicated high similarities between blocs of agroforestry and indigenous tree species $(\mathrm{SI}=0.97, \mathrm{P}>0.05)$, and between blocs of agroforestry and introduced tree species $(\mathrm{SI}=0.85, \mathrm{P}>0.05)$. Less similarities were found between blocs of introduced and indigenous $(\mathrm{SI}=0.63, \mathrm{P}<0.05)$ tree species.

Higher levels in soil $\mathrm{pH}$ were found in plots of indigenous and agroforestry tree species compared to the plots of introduced tree species (Table 2). Despite low levels in soil $\mathrm{pH}$, plots of introduced tree species have higher levels in soil organic carbon, while plots of agroforestry and indigenous tree species have almost the same levels in soil organic carbon (Table 2). There are slightly significant differences $(\mathrm{P}<0.05)$ in soil total nitrogen between plots of indigenous, agroforestry, and introduced tree species (Table 2). Further, plots of introduced tree species are suitable for soil phosphorus compared to the plots of indigenous and agroforestry tree species. However, these differences were not significant $(\mathrm{P}>0.05)$.

Table 2: Variations in soil physicochemical parameters (Mean \pm SD) under agroforestry, exotic and native tree species in the Arboretum of Ruhande in southern Rwanda

\begin{tabular}{|l|l|l|c|c|c|c|c|c|c|c|c|c|}
\hline \multirow{2}{*}{ Tree species } & & $\mathrm{pH}$ & $\begin{array}{c}\text { SOC } \\
(\%)\end{array}$ & $\begin{array}{c}\text { Tot. N } \\
(\%)\end{array}$ & $\begin{array}{c}\text { Av. P } \\
(\mathrm{mg} / \mathrm{kg})\end{array}$ & $\begin{array}{c}\text { CEC } \\
(\mathrm{Meq})\end{array}$ & $\begin{array}{c}\text { AS } \\
(\%)\end{array}$ & $\begin{array}{c}\text { W. cont. } \\
(\%)\end{array}$ & $\begin{array}{c}\text { Clay } \\
(\%)\end{array}$ & $\begin{array}{c}\text { Silt } \\
(\%)\end{array}$ & $\begin{array}{c}\text { Sand } \\
(\%)\end{array}$ & $\begin{array}{c}\text { BD } \\
\left(\mathrm{g} / \mathrm{cm}^{3}\right)\end{array}$ \\
\hline \multirow{2}{*}{ Agroforestry } & Mean & 5.4 & 6.5 & 0.6 & 3.4 & 7.4 & 0.5 & 24.4 & 14.8 & 18.0 & 67.2 & 0.9 \\
\cline { 2 - 13 } & SD & 0.3 & 0.7 & 0.3 & 1.6 & 0.3 & 0.1 & 1.8 & 6.6 & 4.3 & 10.9 & 0.2 \\
\hline \multirow{2}{*}{ Exotic } & Mean & 5.0 & 9.5 & 0.6 & 4.4 & 7.0 & 0.6 & 19.9 & 14.4 & 16.3 & 69.9 & 0.9 \\
\cline { 2 - 12 } & SD & 0.2 & 3.2 & 0.3 & 1.0 & 0.3 & 0.1 & 5.2 & 2.3 & 0.3 & 1.9 & 0.0 \\
\hline \multirow{2}{*}{ Native } & Mean & 5.9 & 6.4 & 0.5 & 3.3 & 7.8 & 0.6 & 25.2 & 13.4 & 16.9 & 68.8 & 0.7 \\
\cline { 2 - 13 } & SD & 0.4 & 0.4 & 0.1 & 0.6 & 0.5 & 0.2 & 4.7 & 1.9 & 2.1 & 3.93 & 0.2 \\
\hline
\end{tabular}

SD: Standard Deviation, Tot N: Total Nitrogen, SOC: Soil Organic Carbon, Av. P: Available Phosphorus, Ag. Stab: Aggregate stability, BD: bulk density, W. cont.: Water Content, CEC: Cation Exchange Capacity.

Soil under plots of indigenous and agroforestry tree species indicated better conditions in cation exchange capacity than the plots of introduced tree species (Table 2). Small significant differences $(\mathrm{P}<0.05)$ in soil aggregate stability were found under plots of agroforestry tree species, while plots of introduced and indigenous tree species have the same proportions in aggregate stability (Table 2). Other significant statistical differences were found in soil 
texture $(\mathrm{P}<0.05)$. Furthermore, soils sampled under plots of indigenous and agroforestry tree species were rich in soil water content. This was found to be $25.2 \pm 4.7$ under plots of indigenous tree species and $24.4 \pm 1.8$ under plots of agroforestry tree species. Lower levels in water content were found in plots of introduced tree species $(19.9 \pm 5.2)$.

The ANOVA test between introduced, indigenous and agroforestry tree species indicated significant difference between sample medians $\left(\chi^{2}=31.5 ; \mathrm{DF}=8 ; \mathrm{P}<0.05\right)$. Even though there is no significant statistical differences between agroforestry and indigenous tree species $\left(\chi^{2}=11.7 ; \mathrm{DF}=5 ; \mathrm{P}>0.05\right)$; significant differences were found between agroforestry and introduced tree species $\left(\chi^{2}=20.69 ; \mathrm{DF}=5 ; \mathrm{P}<0.05\right)$, and between introduced and indigenous tree species $\left(\chi^{2}=18.7 ; \mathrm{DF}=5 ; \mathrm{P}<0.05\right)$. The Pearson linear correlation analysis indicated a positive correlation between all studied soil physicochemical parameters, while few of them showed significant $(\mathrm{P}<0.05)$ statistical differences (Table 3$)$.

Table 3: Pearson correlation coefficients between soil physicochemical properties under plots of agroforestry, native and exotic tree species

\begin{tabular}{|l|c|c|c|c|c|c|c|c|c|c|}
\hline & SOC & Tot N & Av. P & CEC & Ag. Stab & Hum & Clay & Silt & Sand & BD \\
\hline pH & 0.31 & 0.56 & 0.49 & $\mathbf{0 . 0 2}$ & 0.65 & 0.23 & 0.58 & 0.59 & 0.72 & 0.32 \\
\hline SOC & & 0.87 & 0.18 & 0.29 & 0.35 & 0.07 & 0.89 & 0.28 & 0.41 & $\mathbf{0 . 0 1}$ \\
\hline Tot N & & & 0.95 & 0.58 & 0.79 & 0.79 & $\mathbf{0 . 0 2 *}$ & 0.85 & 0.72 & 0.88 \\
\hline Av. P & & & & 0.47 & 0.16 & 0.26 & 0.93 & 0.1 & 0.23 & 0.17 \\
\hline CEC & & & & & 0.64 & 0.22 & 0.6 & 0.57 & 0.7 & 0.3 \\
\hline Ag. Stab & & & & & & 0.42 & 0.77 & 0.06 & 0.06 & 0.33 \\
\hline Hum & & & & & & & 0.81 & 0.36 & 0.48 & 0.09 \\
\hline Clay & & & & & & & & 0.83 & 0.7 & 0.9 \\
\hline Silt & & & & & & & & & 0.13 & 0.27 \\
\hline Sand & & & & & & & & & & 0.4 \\
\hline
\end{tabular}

Tot N: total nitrogen, SOC: soil organic carbon, Av. P: available phosphorus, Ag. Stab: aggregate stability, BD: bulk density, Hum: humidity, CEC: cation exchange capacity, *Significant differences at the 5\% probability level

\section{Discussion}

Actually, soil $\mathrm{pH}$ is used to measure the soil acidity and soil alkalinity. In this regard, the main purpose is to determine the conditions for plant growth, variations in soil nutrients and the levels in soil microbial activities (Wodaja and Alemayehu 2014). In Rwanda,a previous study indicated that soil with pH less than 7.3 is generally acidic (Nabahungu 2013). This study classified soil acidity into different subgroups. The first one contains moderately acidic soils, having the $\mathrm{pH}$ ranging from 5.6 to 6.0. The second one concerns strongly acidic soils having the $\mathrm{pH}$ ranging from 5.1 to 5.5 . The last subgroup is that of very strongly acidic soils with the $\mathrm{pH}$ ranging from 4.5 to 5.0. Relatingthis classification with the findings of this study, 
soils under introduced tree species were very strongly acidic. Those under agroforestry were strongly acidic, while those under indigenous tree species were moderately acidic.

Acidic soils under plots of exotic tree species found in this study were also found in another study done in southern Rwanda (Nsabimana et al. 2009). Different studies in relation with this one showed that high levels in soil $\mathrm{pH}$ under exotic tree speciesmight be related to the availability of exchangeable base cations (Sharma 2011), and to the decrease in base forming cations along the ongoing uptake of nutrients by tree species (Abegaz and Adugna 2015).

Even though soil under exotic tree species have high acidity, they offer better conditions in soil organic carbon.Other studies indicated that variations in soil organic carbon are influenced by the litter fall added to the soil from trees and shrubs (Worku et al. 2014), dead roots, and biochemical activities of mycorrhizal fungi as well (Lemma et al. 2006). Actually, the richness in soil organic carbon is very important for soil ecosystems. Soil organic carbon was also appreciated to supplynutrients in soil, facilitatessoil exchange of cations, soil aggregation, and increasesthe capacity of soil to hold water. In addition, different activities of soil biodiversity are controlled by soil organic carbon (Dudal and Deckers 1993).

Results of this study indicated slight differences in soil total nitrogen across all studied plots, while high levels of available phosphorus were found in plots of introduced tree species. These organic matters supply water and nutrients in soil, and provide suitable physical conditions to plant diversity. Concentration of nitrogen were found to be influenced by fine roots of tree species, and hence doesn't vary significantly, exception for nitrogen fixing trees (Shin et al. 2018). However, this is not the case for available phosphorus which is mainly influenced by soil $\mathrm{pH}$ (Mugoboka 2008). This is in relation with this study, where soils under introduced tree species were acidic and have high levels in phosphorus.

Plots of agroforestry and indigenous tree species offer better conditions in soil cation exchange capacity. This soil parameter is used for measuring the levels of cations used to supply soil nutrients, the capacity of soils for retaining water, and to measure the levels of cations that are readily to be exchanged for the neutralization of negative charges (Wodaja and Alemayehu 2014). Variations in cation exchange capacity is controlled by leaching of exchangeable ions coming from top soils (Nsabimana et al. 2008). In forest plantations, these exchangeable ions are probably increased by high levels of litter fall from tree species, shrubs and herbs (Kassa et al. 2017). They might be also related to the activities and symbiosis of mycorrhizal fungi that reinforce the decomposition rate (Sharma 2011; Howard et al. 1999).

Indigenous tree species were also found to offer better conditions in bulk density and in levels of soil water content. Soil water content was found to be mainly related to less human activities, and high availability of soil organic matters that offer better soil aggregation (Bini et al. 2013). Other studies concluded that soil bulk density is a key factor controlling soilwater holding capacity. The lower is the aggregate stability, the more soil holds water, and more soils contain high water quantity (Cardoso et al. 2013; Tejada et al. 2006). For this 
study, there is no much variations in aggregate stability. We conclude that soil water holding capacity might be influenced by other factors different from the aggregate stability.

Differences in soil texture were found across studied plots. Soil texture is mainly used for estimating soil water availability depending on the land use and land management (Beutler et al. 2002). In soil studies, soil texture is an indicator of water retention and water transport. It is used for evaluating the levels of soil erosion, and for estimating the variability in soil structures (Doran and Parkin 1994). Small differences in soil texture found in this study were related to the structure of Arboretum tree forest plantations, dominated by shrubs, and to the well-developed canopy. This is supported by the findings of another study, where clay and silt soil fractions may be influenced by the canopy of plant diversity, and the protection of root system from leaching and erosion by surface litter coming from trees (Yeshaneh 2015).

\section{Conclusion}

The present study showed that studied tree species affect differently soil physicochemical parameters despite the age. It was found that soils under plots of introduced tree species were acidic, compared to those under indigenous and agroforestry tree species. Introduced tree species offer better conditions in available phosphorus, soil organic carbon, and sand soil, while plots of agroforestry tree species offer better conditions in silt and clay. Indigenous tree species offered better conditions in soil bulk density, water holding capacity, $\mathrm{pH}$, and cation exchange capacity. This researchrevealed that indigenous tree species offer better soil conditions, while agroforestry can serve as alternative. It recommended further studies to assess effects of tree forest plantations in other regions of Rwanda to validate these findings.

\section{Acknowledgements}

The author thanks the University of Rwanda through Sweden research program which supported this research for soil sampling and for laboratory data analysis. He also recognizes the contribution of the managers of the Arboretum of Ruhande during field data collection, and the technical support from the laboratory technicians during soil data analysis.

\section{References}

Abegaz, A., and Adugna, A. 2015. Effects of soil depth on the dynamics of selected soil properties among the highland resources of Northeast Wollega, Ethiopia: Are these signs of degradation? Soil Earth Discussions, 7:3.

Abu-HamdehNidal, H., Al-JalilHamin, F. 1999. Hydraulically powered soil core sampler and its application to soil density and porosity estimation. Soil Tillage Research,52:113120.

AFF [African Forest Forum]. 2011. Forest plantations and woodlots in Rwanda. African Forest Forum (AFF), Nairobi, Kenya. 
Ashford, O.S., Foster, W.A., Turner, B.L., Sayer, E.J., Sutcliffe, L., and Tanner, E.V.J. 2013. Litter manipulation and the soil arthropod community in lowland tropical rainforest. Soil Biology and Biochemistry, 62:5-12.

Beutler, A.N., Centurion, J.F., Souza, Z.M., Andrioli, I., and Roque, C.G. 2002. Water retention in two oxisols under different uses. RevistaBrasileira de Ciência do Solo, 26:829-834.

Bini, D., Santos, C.A, Carmo, K.B., Kishino, N., Andrade, G., Zangaro, W., and Nogueira, M.A. 2013. Effects of land use on soil organic carbon and microbial processes associated with soil health in southern Brazil. Soil Biology,55:117-123.

Campos, J.J., Alpízar, F., Louman, B., Parrotta, J., and Porras, I. 2005. An integrated approach to forest ecosystem services. In: Mery, G., Alfaro, R., Kanninen, M., and Lobovikov, M. (Ed.), Forest in the Global Balance - ChangingParadigms. IUFRO World Series: 97-116.

Cardoso, E.J.B.N., Vasconcellos, R.L.F., Bini, D., Miyauchi, M.Y.H., Alcantra dos Santos, C., Lopes Alves, P.R., Monteiro de Paula, A, ShigueyoshiNakatani, A., Jamil Moraes Pereira and Nogueira, M.A. 2013. Soil health: looking for suitable indicators. What should be considered to assess the effects of use and management on soil health? Scientia Agricola, 70: 274-289.

Clark, D.B, Clark, D.A., Rich, P.M., Wesiss, S., and Oberbauer, S.F. 1996. Landscape-scale evaluation of understory light and canopy structure: Methods and application in a Neotropical lowland rain forest. Canadian Journal of Forest Research, 26:747-757.

Clarke, K.R.1993. Non-parametric multivariate analyses of changes in community structure. Australian Journal of Ecology,18:117-143

Doran, J.W., and Parkin, T.B. 1994. Defining and assessing soil quality. In: Doran, J.W., Coleman, D.C., Bezdicek, D.F., and Stewart, B.A. (Ed.), Defining Soil Quality for sustainable Environment. Soil Science Society of America. Madison, Wisconsin, USA: $3-21$.

Dudal, R, and Deckers, J. 1993. Soil organic matter in relation to soil productivity. In: Mulongoy, K., and Merckx, R. (Ed.), Soil organic matter dynamics and sustainability of tropical agriculture. John Wiley and Son, West Sussex, United Kingdom.

Dyck, B. 2003. Benefits of Planted Forests: Social, Ecological and Economic. Inter-sessional Expert Meeting on the Role of Planted Forests in Sustainable Forest Management, New Zealand, 25 - 27, March 2003.

FAO. 2014. Genetic considerations in ecosystem restoration using native tree species. The state of the world's forest genetic resources thematic study. Italy, Rome. 
GoR [Government of Rwanda]. 2018. Comprehensive food security and vulnerability analysis (CFSVA) report. Kigali - Rwanda.

GoR [Ministry of Natural Resources: MINIRENA, IUCN and WRI]. 2014. Forest Landscape Restoration Opportunity Assessment in Rwanda. Kigali - Rwanda.

GoR [Ministry of Natural Resources: MINIRENA, CGIS - NUR]. 2007. Cartographie Forestière du Rwanda [Forest cartography of Rwanda]. Kigali - Rwanda.

Hammer, O., Harper, D.A.T and Rian, P.D. 2001. Paleontological statistic software package for education and data analysis. Paleontologia Electronica,4: 1-9.

Henok, K., Dondeyne, S., Poesen, J., Frankl, A., and Nyssen, J. 2017. Transition from forest based to cereal based agricultural systems: A review of the drivers of land use change and degradation in southwest Ethiopia. Land Degradation and Development,28: 431449.

Howard, A.E., Olson, B.M., and Cooke, S. 1999. Impact of soil phosphorus loading on water quality in Alberta: A review. Alberta Agriculture, Food and Rural Development,5:41.

Jagger, P., and Pender, J. 2003. The role of trees for sustainable management of less favoured lands: The case of Eucalyptus in Ethiopia. Forest Policy and Economics,5:83-95.

Jürgensen, C., Kollert, W., and Lebedys, A. 2014. Assessment of industrial round wood production from planted forests. Online: http://www.fao.org/3/a-i3384e.pdf. Accessed on 31 January 2018.

Kassa, H., Dondeyne, S., Poesen, J., Frank1, A., and Nysseh, J. 2017. Impact of deforestation on soil fertility, soil carbon and nitrogen stocks: the case of Gacheb catchment in the White Nile basin, Ethiopia. Agriculture, Ecosystems and Environment, 247:273-282.

Lemma, B., Kleja, D.B., Nilson, I., and Olsson, M. 2006. Soil carbon sequestration under different exotic tree species in the southwestern highlands of Ethiopia. Geoderma,136:886-898.

Mishra, A., Sharma, S.D., and Khan, G.H. 2003. Improvement in physical and chemical properties of sodic soil by 3, 6, and 9 years old plantation of Eucalyptus tereticornisBiorejuvenation of sodic soil. Forest Ecology and Management,184:115124.

Mugoboka, D. 2008. Influence of lime and farm yard manure on soil properties. Memoire. Retrieved on 4/6/2019 from: https://www.memoireonline.com

Nabahungu, L. 2013. Rwandan soil health status for sustainable food security and economic growth. Regional Conference on the Eastern and Southern African Soil Partnership. Nairobi, Kenya. 
Nsabimana, D. 2009. Carbon stock and fluxes in Nyungwe forest and Ruhande Arboretum in Rwanda. PhD thesis. Department of plant and environmental sciences. Gothenburg University. Sweden. Retrieved on 26/11/2019 from http://hdl.handle.net/2077/21225

Nsabimana, D., Klemedtson, L., Kaplin, B.A., and Wallin, G. 2008. Soil Carbon and nutrient accumulation under forest plantations in Southern Rwanda. African Journal of Environmental Science and Technology, 2:142-149.

Nsabimana, D., Klemedtsson, L., Kaplin, B.A., and Wallin, G. 2009. Soil $\mathrm{CO}_{2}$ flux in six monospecific forest plantations in southern Rwanda. Soil Biology and Biochemistry, 41:396-402.

Nsengimana, V., Kaplin, A.B., Francis, F., Kouakou, M.M.L., Deckoninck, W., Nsabimana, D. 2018. Use of soil and litter ants (Hymenoptera: Formicidae) as biological indicators of soil quality under different land uses in southern Rwanda. Environmental Entomology, 47(6):1394-1401.

Ospina, C. 2017. Climate and economic benefits of agroforestry systems. Climate Institute, Washington DC, New York.

Rietz, K., and Van der Putten, W.H. 2012. The living soil and ecosystem services. In: Wall DH. (Ed.), Soil Ecology and Ecosystem Services. Oxford University Press: 2-60.

Sayad, E., Hosseini, S.M., Hosseini, V., and Shooshtari, M.H. 2012. Soil Macrofauna in relation to soil and leaf litter properties in tree plantations. Forest Science, 4:170-180

Sharma, K.L. 2011. Effects of introduced-introduced-agroforestry system on soil quality monitoring and assessment. Central Research Institute for dry land agriculture. Accessed on 10/7/2018 from http:/www.crida.in/DRM1-WinterSchool/KLS.pdf.

Shin, U., Satoru, M., Shoji, H., Kojiro, I. and Kenji, F. 2018. Changes in quantity, morphology and nitrogen content of fine roots with stand development in a subalpine for-wave forest. Forest Research, 23 (6):336-6345.

Sjoerd, P., López-Acosta, J.C., Gomez-Díaz, J.A., and Lascurain-Rangel, M. 2018. Floristic diversity and cultural importance in agroforestry systems on small-scale farmer's livelihoods in central Veracruz, México. Sustainability,10:279.

Tejada, M., Garcia, C., Gonzales, J.L., and Hernandez, M.T. 2006. Organic amendment based on fresh and composted beet vinasse: influence on physical, chemical and biological properties and wheat yield. America Journal of Soil Science,70:900-990.

Tellen, V.A., and Yerima, B.P.K. 2018. Effects of land use change on soil physicochemical properties in selected areas in the North West region of Camerron. Environmental Systems, 2018: 7-3.https://doi.org/10.1186/s40068-018-0106-0. 
Tesfaye, M.A., Bravo, F., Ruiz-Peinado, R., Pando, V., and Bravo-Oviedo, A. 2016. Impact of changes in land use, species and elevation on soil organic carbon and total nitrogen in Ethiopian Central Highlands. Geoderma,262:70-79.

Verdoodt, A., and Van Ranst, E. 2003. Land Evaluation for Agricultural Production in the Tropics. A Large-Scale Land Suitability Classification for Rwanda. Ghent University. Laboratory of Soil Science.

Vignozzi, N., Agnelli, A.E., Brandi, G., Gagnarli, E., Goggioli, D., Lagomarsino, A., Pellegrini, S., Simoncini, S., Sauro, S., Valboa, G., Caruso, G., and Gucci, R. 2018. Soil ecosystem functions in a high-density olive orchard managed by different soil conservation practices. Applied soil ecology, 134:64-76.

Watson, M.E, and Brown, J.R. 1998. The pH and Lime Requirement. In: Denning, J., Eliason, R., Goos, R.J., Hoskins, B., Nathan, M.V., and Wolf, A. (Ed.). Recommended Chemical Soil Test Procedures for the North Central Region. Missouri agricultural Experiment Station SB 1001:13-16.

Wodaja, A., and Alemayehu, A. 2014. Analysis of selected physicochemical parameters of soils used for cultivation of Garlic (Allium sativum L.). Science, Technology and Arts Research Journal,3(4):29-35.

Wood, J. 2018. Earth has more trees than it did 35 years ago - but there is a huge catch. World Economic Forum. Accessed on 6/9/2019 from https://www.weforum.org

Worku, G., Bantider, A., and Temesgen, H. 2014. Effects of land use/land cover change on some soil physical and chemical properties in Ameleke micro-watershed Gedeo and Borena zones, South Ethiopia. Environment and Earth Science, 4:13-24.

Yeshaneh, G.T. 2015. Assessment of Micronutrient Status in Different Land Use Soils in Maybar Lake Watershed of Albuko District, South Wello Zone, North Ethiopia." American Journal of Environmental Protection, 3 (1): 30-36. 